\title{
LITERASI MEDIA DI YAYASAN PERGURUAN MARKUS TANGERANG
}

\author{
Rambu Naha, Rosse Mince Hutapea \\ ${ }^{1}$ Universitas Pelita Harapan \\ ${ }^{2}$ Universitas Pelita Harapan
}

Rambu.naha@uph.edu, Rosse.hutapea@uph.edu

\begin{abstract}
Abstrak
Perkembangan teknologi komunikasi digital terutama dengan kehadiran internet, memberikan dampak seperti kemudahan dalam membagikan informasi maupun munculnya berbagai persoalan karena kurang bijaknya masyarakat memahami informasi yang diterima. Edukasi terkait literasi media dapat memberikan pemahaman dan pemberdayaan kepada audiens terkait bagaimana menggunakan media (Tully \& Vraga, 2017). Melalui Pengabdian kepada Masyarakat (PkM), Program Studi Pendidikan Jarak Jauh Ilmu Komunikasi Universitas Pelita Harapan mengadakan edukasi terkait literasi media bagi siswa, guru, dan orang tua di Yayasan Perguruan Markus Tangerang. Kegiatan ini dilakukan dalam tiga rangkaian kegiatan edukasi yakni seminar, permainan edukatif dan diskusi kelompok. Melalui edukasi literasi media, siswa, guru, dan orang tua mampu untuk mengkritisi informasi yang diperoleh dan dapat memanfaatkan perangkat digital untuk mencegah berkembangnya informasi yang tidak benar di masyarakat. Selain itu, setelah memperoleh pemahaman terkait Digital Literasi, para peserta diharapkan juga mampu untuk menjadi agen untuk menyebarkan pemahaman literasi media yang diperoleh baik di sekolah, di keluarga, maupun masyarakat luas.
\end{abstract}

Kata Kunci : literasi media, edukasi, critical thinking

\section{PENDAHULUAN}

Pemanfaatan teknologi informasi dan komunikasi kini telah menjadi bagian yang tidak dapat terpisahkan dari kehidupan manusia, termasuk juga di Indonesia. Berdasarkan Digital Report 2019 menunjukan bahwa dari total 268,2 juta penduduk Indonesia, 56\% merupakan pengguna internet dan media sosial atau masing-masing sebesar 150 juta jiwa, sedangkan angka pengguna perangkat mobile mencapai 355, 5 juta jiwa (Hootsuite \& We Are Social, 2019). Data tersebut menunjukan bahwa lebih dari sebagian besar masyarakat Indonesia terpapar internet serta kepemilikan perangkat mobile rata-rata lebih dari 1 unit. Berbagai hal dapat dilakukan melalui perangkat mobile yang terkoneksi dengan internet, mulai dari berbelanja, melakukan transfer dana, membayar listrik, membaca berita, menonton televisi hingga membangun interaksi melalui berbagai platform media sosial. Tetapi tidak dapat dipungkiri bahwa pemanfaatan perangkat mobile dan juga internet serta kecepatan penyebaran informasi masih belum didukung oleh kesiapan masyarakat dalam mengelola informasi yang diterima. Data dari DailySoacialid menunjukan bahwa 75\% masyarakat Indonesia masih sulit untuk dapat mendeteksi informasi hoaks. Lebih lanjut dailysocial.id juga menunjukan bahwa hanya $32,87 \%$ responden yang menunjukan ketertarikan untuk mencari tahu informasi yang diterima secara utuh dan melakukan klarifikasi mengenai kebenaran informasi tersebut. (Dailysocialid, 2018).

Kurangnya edukasi mengenai pemanfaatan internet yang marak melalui perangkat mobile serta 
aplikasi dan platform media sosial lainnya tentu saja dapat memicu kesesatan berpikir serta konflik baik itu dalam level personal, kelompok, serta masyarakat. Pada Oktober 2018, masyarakat Indonesia digemparkan oleh informasi yang mengatakan bahwa aktivis Ratna Sarumpaet mengalami penganiayaan. Berita ini kemudian disebarkan oleh sejumlah tokoh nasional melalui media sosial serta jumpa pers. Tetapi kemudian setelah dilakukan penyelidikan oleh pihak kepolisian terbukti bahwa informasi tersebut tidak benar dan Ratna Sarumpaet mengakui kebohongan yang dilakukannya. Pengalaman ini dapat dijadikan pelajaran penting bahwa informasi yang diterima perlu untuk diverifikasi kebenarannya sebelum mempercayai apalagi menyebarkannya. Tentu kasus Ratna Sarumpaet hanya salah satu dari banyak kasus yang menunjukan bahwa masyarakat Indonesia masih mudah digiring pemikirannya oleh informasiinformasi tertentu tanpa melakukan verifikasi terlebih dahulu.

Melihat fakta makin tingginya penetrasi pengguna mobile dan internet di Indonesia, maka penting untuk memberikan edukasi bagi masyarakat terkait literasi media. Buckingham (dikutip dari Kemerer, 2013) mengatakan bahwa edukasi media atau literasi media merupakan pengetahuan, keterampilan dan kemampuan untuk menggunakan dan menginterpretasikan media. Kemampuan literasi media yang baik menjadikan seorang individu untuk tidak mudah terprovokasi dengan berbagai informasi yang diterima, sebaliknya dapat berpkirir kritis dalam memilah informasi maupun dalam memanfaatkan teknologi itu sendiri.

Sebagai lembaga pendidikan tinggi, maka Universitas Pelita Harapan (UPH) memiliki tanggung jawab sosial sebagai implementasi tri dharma perguruan tinggi yakni mengadakan Pengabdian kepada Masyarakat (PkM), dengan turut memberikan edukasi terkait literasi media. UPH melalui Program Studi Pendidikan Jarak Jauh (PJJ) memilih Yayasan Perguruan Markus sebagai lokasi untuk memberikan edukasi literasi media. Sekolah Markus berdiri sejak 1989 dan saat ini memiliki lebih dari 300 siswa dari tingkat Sekolah Dasar (SD), Sekolah Menengah Pertama (SMP), Sekolah Menengah Atas (SMA) dan Sekolah Menengah Kejuruan (SMK) dan Sekolah Luar Biasa (SLB). Karakteristik sosial ekonomi siswa berasal dari ekonomi menengah dan bawah, tinggal di daerah Tangerang dan umumnya orang tua bekerja di sektor informal.

Berdasarkan informasi dari para guru Yayasan Perguruan Markus Tangerang, siswa umumnya sudah mengenal dan menggunakan perangkat komunikasi digital. Bahkan cukup banyak yang memiliki handphone atau smartphone pribadi. Tidak sedikit siswa yang membawa gadget ke sekolah. Meskipun sekolah telah mengupayakan membuat aturan untuk penggunaan handphone di sekolah pada saat jam belajar, namun persoalan terkait penggunaan gadget masih cukup signifikan, sehingga berdampak terhadap perilaku siswa yang berakibat pada proses belajar mengajar.

Beberapa masalah yang disampaikan para guru diantaranya perhatian siswa sulit konsentrasi, berpotensi memberi pengaruh negatif terhadap sikap dan perilaku siswa dalam interaksi sosial di sekolah, dalam hubungan dengan lawan jenis, pornografi, dan penyimpangan seksual, ketergantungan pada fitur hiburan seperti game online, film, salah dalam berjejering sosial di dunia maya, serta dampak negatif terhadap kesehatan. Persoalan yang disampaikan tersebut tentunya tidak hanya masalah yang dihadapi siswa semata, namun juga menjadi masalah bagi guru-guru dan orang tua siswa.

Untuk mengatasi masalah sebagaimana yang disampaikan oleh guru-guru sekolah Yayasan Perguruan Markus Tangerang, maka literasi media menjadi solusi yang perlu ditawarkan. Adapun peserta yang diberikan edukasi literasi media merupakan para Siswa Sekolah Menengah Pertama (SMP), Sekolah Menengah Atas (SMA), dan Sekolah Menengah Kejuruan (SMK) Markus dan para guru serta orang tua murid. Kebutuhan edukasi literasi media perlu diberikan kepada setiap kelompok usia karena tidak dapat dipungkiri bahwa paparan media dan internet saat ini juga terjadi pada setiap orang. Berdasarkan survey yang dikeluarkan oleh Asosiasi Penyelenggara Jasa Internet Indonesia (APJII), pengguna internet berada pada rentang usia 13 sampai dengan 54 tahun (APJII, 2018). 


\section{METODE}

Melihat beragamnya kelompok usia yang perlu untuk diberikan edukasi terkait literasi media, maka Program Studi PJJ Ilmu Komunikasi memberikan pendekatan yang berbeda pula mengenai literasi media. Program literasi media diawali dengan memberikan seminar kepada seluruh peserta untuk membuka wawasan peserta mengenai kondisi media saat ini dan kasus-kasus yang terjadi akibat tidak bijaknya masyarakat menggunakan teknologi informasi dan komunikasi. Seminar menjadi kegiatan pertama yang diberikan dalam rangkaian literasi media di Yayasan Perguruan Markus. Seminar ini menjadi langkah awal untuk membuka wawasan dan memberikan edukasi bagi peserta. Sesi seminar kemudian dilanjutkan dengan dua kegiatan lainnya untuk semakin memperdalam pemahaman peserta terkait literasi media. Kedua kegiatan tersebut adalah permainan ( games) edukatif dan diskusi kelompok. Permainan edukatif ditujukan kepada siswa/I, sedangkan diskusi kelompok ditujukan bagi guru dan orang tua.

Permainan edukatif dipilih untuk diberikan bagi para siswa agar mereka dapat secara kritis memahami literasi media dalam berbagai konteks kehidupan. Dengan keterampilan untuk memecahkan masalah yang diformulasikan dalam permainan, maka para siswa diharapkan untuk memiliki keterampilan penyelesaian masalah dalam konteks kehidupan sehari-hari (Choi, Pursel, and Stubbs, 2017). Sedangkan dengan pembelajaran berbasis diskusi dapat efektif untuk diterapkan pada orang tua dan guru (Choe, $\mathrm{K}$, dkk dikutip dari Abedini \& Parvizy, 2019).

Pelaksanaan PkM di Yayasan Perguruan Markus dilakukan dalam beberapa tahapan guna menghasilkan sebuah pembelajaran yang komprehensif serta mudah untuk diimplementasikan dalam konteks kehidupan peserta. Beberapa tahapan yang dilakukan oleh Program Studi PJJ Ilmu Komunikasi sebelum melakukan kegiatan PkM adalah:

1. Menentukan Roadmap kegiatan PkM secara berkelanjutan

Sebelum mulai melakukan kegiatan Pengabdian kepada Masyarakat, maka program studi membuat peta jalan (roadmap) terkait dengan arah kegiatan pengabdian kepada masyarakat. Roadmap pelaksanaan kegiatan PkM PJJ Ilmu
Komunikasi berfokus pada berkontribusi terhadap upaya penyelesaian masalah komunikasi di masyarakat khususnya yang berkaitan dengan pemanfaatan teknologi informasi dan komunikasi. Adapun roadmap PkM Program Studi PJJ Ilmu Komunikasi adalah sebagai berikut:
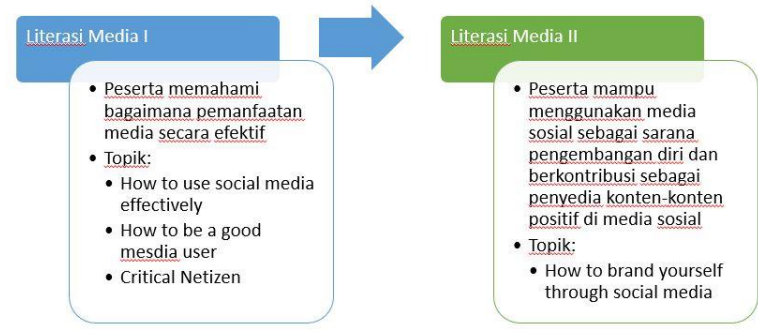

Gambar 1. (Roadmap PkM PJJ Ilmu

Komunikasi)

Tahap pertama adalah edukasi Literasi media tahap dasar, dimana peserta diberikan edukasi dan wawasan mengenai bagaimana seharusnya menyikapi setiap informasi yang diterima melalui media dan internet. Tahapan pertama ini bertujuan untuk membangun kerangka berpikir yang benar terkait pemanfaatan media dan internet. Pada tahapan kedua, peserta mulai diarahkan untuk dapat memanfaatkan teknologi komunikasi dan internet sebagai sarana pengembangan diri dan ikut berkontribusi dalam membagikan konten-konten yang edukatif khususnya melalui media sosial

2. Koordinasi dengan Lokasi PkM

Sebelum pelaksanaan kegiatan PkM, Program Studi (Prodi) PJJ Ilmu Komunikasi melakukan survey untuk menentukan lokasi yang akan menjadi sasaran pemberian edukasi literasi media. Lokasi yang dipilih merupakan lokasi yang memiliki kebutuhan terkait dengan literasi media, sehingga kehadiran Prodi PJJ Ilmu Komunikasi dapat berkontribusi untuk memberikan solusi atas permasahalan yang dihadapi. Demikian tahapan ini juga terjadi pada pemilihan Yayasan Perguruan Markus Tangerang. Pihak sekolah merasa membutuhkan edukasi terkait literasi media, karena melihat persoalan yang terjadi di kalangan siswa-siswi, guru dan juga orang tua. 
3. Persiapan Pelaksanaan PKM

Pada tahapan ini, Program Studi PJJ Ilmu Komunikasi mengajukan rancangan pelaksanaan kegiatan kepada pihak Yayasan Perguruan Sekolah Markus. Pengajuan rancangan kegiatan ini juga ditindaklanjuti dengan koordinasi terkait teknis pelaksanaan kegiatan pada hari H. Poinpoin yang dikoordinasikan adalah terkait dengan bentuk kegiatan, waktu, penggunaan ruangan, perlengkapan serta pihak yang bertanggung jawab dari kedua belah pihak.

4. Pelaksanaan PKM

Setelah kedua belah pihak menyetujui rancangan pelaksanaan kegiatan PkM literasi media, maka kegiatan PkM pun dilakukan pada Sabtu, 26 November 2019 bertempat di Yayasan Perguruan Markus Tangerang. Peserta yang mengikuti kegiatan ini terdiri dari 120 siswa (SMP, SMA, SMK), 25 orang guru, dan 40 orang tua murid. Kegiatan berlangsung sesuai dengan perencanaan yang sudah ditetapkan sebelumnya.

5. Evaluasi I

Evaluasi tahap I merupakan evaluasi yang diberikan oleh peserta terkait pelaksanaan kegiatan PkM Literasi media. Evaluasi ini penting untuk mengetahui apakah peserta memiliki pemahaman yang tepat terkait dengan edukasi Literasi media yang diberikan. Disamping itu, melalui evaluasi ini diharapkan peserta juga dapat memberikan saran dan kritik yang membangun untuk perbaikan di waktu mendatang.

\section{Evaluasi II}

Evaluasi pada tahapan kedua merupakan evaluasi yang diberikan oleh pihak sekolah setelah keseluruhan rangkaian PkM berlangsung. Evaluasi ini bertujuan untuk melihat apakah pihak sekolah masih membutuhkan edukasi mengenai Literasi media untuk tahapan yang kedua. Tahapan yang kedua akan berfokus kepada pengembangan diri siswa melalui pemanfaatan media sosial, sesuai dengan peta jalan PkM Program Studi PJJ Ilmu Komunikasi

\section{HASIL DAN PEMBAHASAN}

\section{Seminar}

Kegiatan pertama yang dilakukan dalam rangkaian PkM Literasi media adalah memberikan Seminar dengan tujuan untuk memberikan pengetahuan dasar mengenai kondisi media saat ini. Sesi seminar ini diberikan kepada seluruh kelompok peserta mulai dari siswa SMP, SMA/K, guru, dan orang tua. Terdapat 120 siswa (SMP, SMA, SMK), 25 orang guru, dan 40 orang tua murid yang mengikuti seminar ini. Pengetahuan yang diberikan dalam seminar ini mencakup gambaran umum mengenai kondisi perkembangan teknologi komunikasi di era digital dan penetrasi pemakaiannya di Indonesia.

Dengan adanya berbagai media sosial, tentu penyebaran informasi berlangsung dengan sangat pesat. Terkadang pengguna media sosial begitu naif untuk langsung menyerap semua informasi yang diterima sebagai sebuah kebenaran. Hal ini menjadi sebuah ancaman bagi pengguna media sosial yang dapat menjadi korban berita hoax atau bahkan menjadi penyebar berita hoax tersebut.

Pengguna media digital perlu mamahami apa itu hoaks dan bagaimana cara membedakan dengan berita yang benar. Pengertian hoaks mengacu dari Kamus Besar Bahasa Indonesia (KBBI) daring mendefinisikan fakta sebagai "Hal (keadaan, peristiwa) yang merupakan kenyataan; sesuatu yang benar-benar ada atauterjadi."

Sedangkan hoaks sebagaimana pengertian yang dikemukakan Robert Nares (1882) Dalam bukunya, "A Glossary: Or, Collection of Words, Phrases, Names dan Allusions to Customs", mencatatkan, istilah hoaks pertama kali digunakan di Inggris pada abad ke-18. Kata ini muncul dari kata hocus (Latin), yang merujuk pada hocus pocus yang memiliki arti "to cheat" atau "menipu". Untuk lebih memberikan gambaran yang jelas, peserta mendapatkan paparan contoh-contoh berita hoaks yang tersebar di media, dari aspek kesenian, kesehatan, politik, ekonomi, dan peluang bisnis.

Dalam penyuluhan juga dijelasakan bagaimana paparan hoaks dapat disebarkan ke berbagai kalangan pengguna media dan dampak yang ditimbulkan. Peserta juga dijelaskan bahwa respon yang dihasilkan dari informasi yang diterima 
pengguna media sosial akan memiliki konsekuensi yang berbeda.

Konsekuensi serta landasan hukum dari penyebaran hoaks juga disampaikan untuk memberikan kesadaran dan kehati-hatian dalam mengakses dan menggunakan informasi dari media digital. Ditegaskan bahwa menyebarkan berita hoaks bukanlah bentuk kebebasan berpendapat yang dijamin oleh negara, melainkan sebuah kejahatan yang akan menimbulkan konsekuensi bagi para pelaku. Seperti dikutip dari laman resmi pemerintah Jawa Tengah berikut ini "hoax tidak ada kaitannya dengan kebebasan berpendapat yang dijamin Undang-undang Dasar 1945" (Diskominfo Jateng)

\section{Permainan Edukatif}

Setelah semua peserta mendapatkan wawasan mengenai literasi media, maka permainan edukatif dipilih untuk membantu memperdalam pemahaman peserta serta menstimulasi peserta untuk belajar berpikir kritis terkait pemanfaatan media dalam kehidupan sehari-hari. Permainan ini khusus diberikan kepada siswa/I SMP, SMA, dan SMK, sedangkan untuk guru dan orang tua, pendalaman materi seminar diberikan dalam bentuk diskusi yang didampingi oleh fasilitator serta pemimpin kelompok diskusi. Tema games yang dipilih adalah 'Cerdas Bermedia'. Adapun 2 hal yang menjadi landasan dalam penyelenggaraan games adalah:

1. Media hadir dengan tujuan tertentu

Apa yang disajikan dalam media sangat bergantung pada siapa orang dibalik media tersebut dan apa yang menjadi nilainya. Dalam hal politik misalnya, jika pemilik media mendukung calon presiden tertentu, maka pemberitaan di media tersebut adalah hal-hal yang positif mengenai calon presiden yang didukung oleh pemilik media.

2. Media menyampaikan sebagian informasi Informasi yang disajikan media seringkali merupakan sebagian dari keseluruhan peristiwa yang terjadi. Mengapa demikian? Karena media harus menyeleksi atau memilah informasi yang mana yang harus diangkat yang sesuai dengan nilai dari organisasi tersebut.

The center of Media Literacy (dikutip dari Herbert, dkk 2018) menyebutkan bahwa terdapat 5 pertanyaan kunci untuk menjelaskan literasi media kepada remaja yakni:

1. Siapa yang membuat pesan tersebut?

2. Teknik kreatif apa yang digunakan untuk menarik perhatian saya?

3. Bagaimana mungkin setiap orang dapat memahami informasi secara berbeda

4. Apa nilai, gaya hidup, atau sudut pandang yang ada atau yang diabaikan dalam informasi?

5. Mengapa informasi ini dikirmkan?

Berdasarkan landasan diatas, maka games yang dipilih untuk mempertajam pemahaman peserta adalah:

\section{Permainan I "Cerdas Menilai dan Memilih Informasi" \\ Tujuan:}

1. Peserta mengetahui cara penyebaran pesan/informasi di media massa

2. Peserta terampil dalam menilai dan memilih informasi dari media massa

3. Peserta memiliki sikap kritis dalam menerima informasi dari media massa

Waktu: 30 menit

Tempat: Ruang kelas tanpa meja dan kursi

Peralatan: Kertas berisi informasi/pesan untuk setiap kelompok

Jumlah kelompok: 3-5 kelompok masingmasing yang terdiri dari 10-15 anggota

\section{NAMA KEGIATAN: PESAN BERANTAI}

1. Peserta dibagi kedalam beberapa kelompok.

2. Masing-masing kelompok terdiri dari $10-15$ orang.

3. Masing-masing kelompok berdiri membentuk satu barisan.

4. Perwakilan satu orang dari setiap kelompok (anggota yang berbaris paling depan) akan menerima informasi pertama dari fasilitator.

5. Perwakilan kelompok membaca dan menghafal informasi yang diberikan panitia.

6. Perwakilan kelompok diminta untuk kembali ke barisannya dan membisikan kata yang sudah dihafalkan ke anggota kelompok yang berdiri tepat disampingnya.

7. Informasi tersebut kemudian diteruskan dari anggota yang satu ke anggota yang lainnya secara berurutan. 
8. Anggota yang terakhir diminta untuk maju ke depan dan menyampaikan pesan yang sudah ia terima.

9. Perhatikanlah apakah pesan yang ia terima sama dengan apa yang diterima pertama kali oleh perwakilan pertama yang menerima pesan.

\section{PENUTUP:}

1. Peserta diajak untuk menyampaikan kembali pesan apa yang mereka peroleh dari games tersebut.

2. Fasilitator memberikan kesimpulan dari games tersebut berupa:

a. Pesan lebih akurat apabila diperoleh dari pihak pertama. Semakin banyak pihak yang meneruskan sebuah pesan maka kemungkinan besar pesan tersebut semakin berkurang dari pesan yang sesungguhnya.

b. Pesan yang disampaikan melalui media elektronik atau media sosial juga memiliki kemungkinan yang sama. Setiap orang yang membagikan informasi dapat mengurangi, menghilangkan atau menambah pesan asli yang diterima. Semakin banyak orang yang membagikan informasi tersebut maka semakin besar peluang berkurangnya makna asli dari pesan tersebut. Apabila informasi diperoleh berupa link dari portal berita terpercaya barulah anda bisa menerima informasi tersebut dengan tetap kritis!

c. Jangan mudah percaya dengan informasi yang anda dengar dari orang lain apalagi dari sumber yang tidak terpercaya. Cari tau sumber informasinya, buktikan apakah sumber tersebut akurat atau tidak.

\section{Permainan II "See the Bigger Picture" Tujuan:}

1. Peserta mengetahui cara media memproduksi informasi
2. Peserta terampil memilah informasi yang disajikan media

3. Peserta memiliki sikap kritis dalam menerima informasi dari media massa

Waktu: 30 menit

Tempat: Ruang kelas tanpa meja dan kursi Peralatan:

1. Lembar jawaban untuk setiap kelompok

2. Lcd + Projector, jika tidak ada maka menggunakan lembar jawaban bergambar

Jumlah kelompok: 5-10 kelompok yang terdiri dari 5-10 anggota

NAMA KEGIATAN: TEBAK GAMBAR

Bagilah audiens ke dalam kelompok yang terdiri dari 5-10 orang

\section{Apabila games ini menggunakan LCD Proyektor:}

a. Tampilkan slide per slide yang berisi gambar yang telah di framing.

b. Meminta masing-masing kelompok untuk menuliskan pada lembar jawaban gambar apa yang sedang mereka lihat pada slideslide tersebut.

c. Setelah semua gambar framing selesai ditampilkan dan kelompok telah menuliskan jawaban, kelompok diajak melihat masingmasing gambar framing tadi dalam versi gambar aslinya.

d. Kemudian peserta diajak untuk menyampaikan pesan apa yang mereka dapatkan dari games tebak gambar tersebut.

\section{Apabila Games ini tidak menggunakan LCD} Proyektor:

a. Fasilitator membagikan handout berisi gambar framing yang sudah disiapkan sebelumnya.

b. Kelompok diminta untuk menuliskan gambar apa yang terdapat pada handout yang mereka terima.

c. Apabila kelompok selesai mengisi makna gambar yang mereka amati, mintalah kelompok untuk memperhatikan gambar asli yang ada pada fasilitator

d. Kemudian peserta diajak untuk menyampaikan pesan apa yang mereka dapatkan dari games tebak gambar tersebut. 


\section{PENUTUP:}

Fasilitator memberikan kesimpulan dan menjelaskan makna dari games tebak gambar tersebut yaitu:

a. Media memiliki kemampuan yang terbatas untuk dapat menyampaikan kejadian secara utuh. Terkadang media hanya mengambil atau menyajikan sebagian dari keseluruhan peristiwa yang terjadi. Hal ini tidak saja hanya terjadi pada gambar (foto) tetapi juga pada bentuk informasi lainnya (video dan tulisan).

b. Mengapa media hanya mampu menyajikan sebagian dari keseluruhan peristiwa? Karena media dibentuk dengan tujuan tertentu yang berbeda satu dengan yang lain. Media yang tujuannya provokatif akan cenderung menyajikan hal-hal provokatif dari sebuah peristiwa meskipun ada hal positif yang bisa diangkat dari peristiwa yang sama.

c. Bijaklah dalam menerima informasi yang disampaikan media. Carilah sumber informasi kredibel lainnya untuk memperoleh gambaran secara utuh mengenai sebuah peristiwa

\section{Permainan III "See the Bigger Picture" Tujuan:}

1. Peserta mengetahui kondisi media massa saat ini

2. Peserta memiliki keterampilan untuk mengidentifikasi kebenaran informasi yang disajikan di media massa

3. Peserta memiliki sikap kritis dalam menerima informasi dari media massa

WAKTU: 30 menit

TEMPAT: Ruang kelas tanpa meja dan kursi PERALATAN:

1. Kain penutup mata

2. Kertas berisi nama karakter hewan

JUMLAH KELOMPOK: 3-5 kelompok, usahakan jumlah anggota per kelompok sama

\section{NAMA KEGIATAN: MENCARI}

\section{KEBENARAN}

1. Peserta dibagi kedalam lima kelompok (atau beberapa kelompok dengan jumlah anggota yang sama).
2. Masing-masing peserta di dalam kelompok diberikan nama karakter hewan berserta kain penutup mata.

3. Peserta tiap kelompok diminta untuk menghafal karakter tersebut dan tidak boleh memberitahukan kepada teman lain yang ada di kiri kanan mereka.

4. Peserta diminta untuk menutup mata menggunakan kain yang sudah dibagikan.

5. Setelah semua peserta tertutup matanya dengan kain yang tersedia, maka fasilitator mulai untuk menuntun peserta dan memindahkan secara acak poisisi berdiri dari masing masing peserta.

6. Posisi berdiri peserta dengan karakter yang sama diatur menjadi saling berjauhan satu sama lain.

7. Peserta diminta untuk mencari peserta lain yang memiliki karakter yang sama, dengan cara meniru suara dari karakter yang mereka miliki. Misalnya karakter anjing dengan suara menggonggong.

8. Games dilakukan secara serentak sehingga setiap peserta harus fokus mencari suara yang sama diantara suara karakter lain.

\section{PENUTUP:}

1. Mintalah peserta untuk menyampaikan pesan apa yang mereka dapatkan dari games tersebut.

2. Fasilitator memberikan kesimpulan mengenai makna dari games tersebut dalam kaitannya dengan literasi media:

a. Di kehidupan yang serba digital dengan akses yang cepat, kita sulit untuk tidak menerima beragam informasi yang silih berganti disajikan berbagai media atau aplikasi yang ada. Dari beragam informasi yang disajikan ada informasi yang benar tetapi ada juga informasi yang menyesatkan. Sebagai pengguna media yang akan bertemu dengan berbagai informasi, kita perlu fokus pada mencari informasi-informasi yang benar, informasi-informasi yang memperkaya wawasan kita, bukan mencari informasi yang menyesatkan. 
b. Sebagai pengguna media, kita tidak boleh menjadi pengguna yang pasif yang menerima tanpa mengkritisi informasi-informasi yang disajikan. Kita perlu secara aktif berfokus pada mencari kebenaran dari informasi yang kita terima.

Dalam pelaksanaan games ini, setiap siswa dibagi menjadi beberapa kelas, dan setiap kelas terdiri dari 4-5 kelompok. Setiap kelas didampingi oleh 4-5 fasilitator yang berperan untuk mengarahkan jalannya permainan serta membantu siswa untuk memahami keterkaitan antara games dengan kontek literasi media. Fasilitator merupakan mahasiswa/i Program Studi PJJ Ilmu Komunikasi yang telah terlebih dahulu di latih untuk dapat membawakan materi games dengan baik.

\section{Diskusi Kelompok}

Sesi diskusi kelompok difokuskan pada guru dan orang tua murid dari siswa di Yayasan Perguruan Markus Tangerang. Para guru dan orang tua terlihat aktif dan antusias terlibat dalam sesi diskusi tersebut. Hal-hal yang didiskusikan oleh guru dan orang tua dalam diskusi tersebut adalah terkait dengan bagaimana peranan orang tua dalam memonitor anak-anak mereka dalam penggunaan internet, halhal apa saja yang perlu mereka antisipasi agar anak dapat memanfaatkan media dan internet untuk hal yang bermanfaat, peluang-peluang positif apa saja yang bisa diperoleh orang tua dan anak terkait dengan pemanfaatan teknologi komunikasi dan internet.

Sesi diskusi ini dipandu oleh satu orang dosen sebagai pemimpin diskusi serta didampingi oleh beberapa mahasiswa. Keberadaan mahasiswa dalam diskusi tersebut adalah untuk memberikan pandangan atau testimoni mengenai seperti apa kecenderungan remaja atau anak muda terkait dengan penggunaan perangkat mobile dan internet. Mengetahui kondisi ini dari perspektif anak akan memudahkan orang tua untuk memiliki gambaran terkait dengan pemanfaatan perangkat mobile dan internet

Secara keseluruhan pelaksanaan $\mathrm{PkM}$ Literasi media bagi siswa dan orang tua Yayasan Perguruan Markus Tangerang dinilai berhasil dan peserta dapat memahami inti pesan yang ingin disampaikan melalui kegiatan $\mathrm{PkM}$ tersebut. Hal ini dapat dilihat dari evaluasi dan komentar yang diberikan oleh para peserta seperti berikut:

\begin{tabular}{|c|c|c|c|}
\hline No & Deskripai & $\mathrm{Ya}_{\mathbf{a}}$ & Tidak \\
\hline 1 & $\begin{array}{l}\text { Apakah anda pernah mengikuti pelatihan pengenalan literasi digital } \\
\text { sebelumnya? }\end{array}$ & 16 & 43 \\
\hline 2 & Apakah menurut anda literasi digital cangat penting dan dibutuhlikan? & 59 & 0 \\
\hline 3 & $\begin{array}{l}\text { Apakah materi yang disampaikan dalam penyuluhan dan workshop literasi } \\
\text { digital ini dapat dipahami dengan mudah oleh peserta? }\end{array}$ & 56 & 3 \\
\hline 4 & $\begin{array}{l}\text { Apakah setelah mengikuti penyuluhan dan pelatihan ini anda dapat } \\
\text { memahami tentang literasi digital? }\end{array}$ & 58 & 1 \\
\hline 5 & $\begin{array}{l}\text { Apakah penyuluhan dan pelatihan literasi digital ini dapat meningikatkan } \\
\text { minat anda untuk menggunakan digital media dengan baik dan benar? }\end{array}$ & s5 & 4 \\
\hline 6 & $\begin{array}{l}\text { Apakah cara penyampaian materi dan kegiatan workshop literasi digital ini } \\
\text { menarik dan sangat membantu anda memahami tentang literasi digital? }\end{array}$ & 58 & 1 \\
\hline 7 & Apakah para fasilitator (pelatih) menguasai materi literasi digital? & 59 & 0 \\
\hline 8 & $\begin{array}{l}\text { Apakah menurut anda kegiatan penyuluhan literasi digital sebaiknya } \\
\text { dilakukan secara berkala? }\end{array}$ & 41 & 18 \\
\hline
\end{tabular}

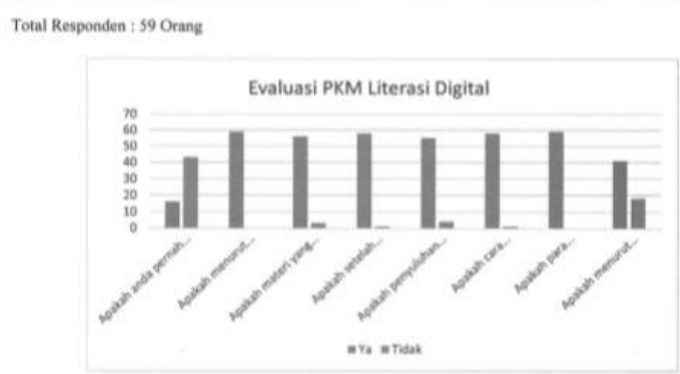

Gambar 2. (Hasil Evaluasi Kegiatan PkM Literasi media)

KRITIK DAN SARAN

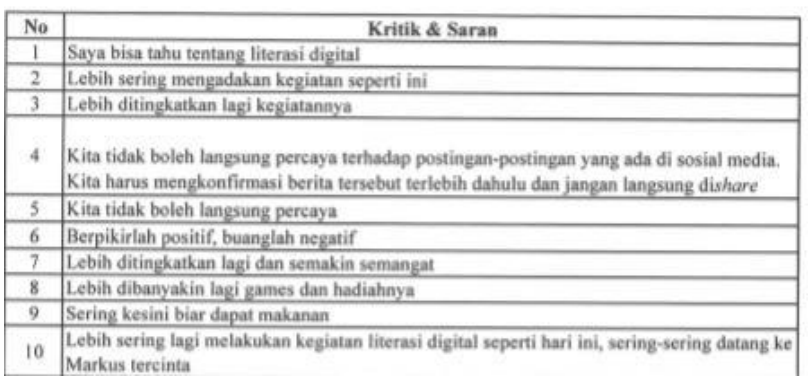

Gambar 3. (Komentar peserta PkM Literasi media)

Komentar yang disampaikan pada kolom kritik dan saran dapat menggambarkan pemahaman peserta yang sesuai dengan fokus utama pelaksanaan kegiatan PkM ini. Pernyataan berupa "Kita tidak boleh langsung percaya terhadap postinganpostingan yang ada di sosial media. Kita harus mengkonfirmasi berita tersebut terlebih dahulu dan jangan langsung di share", mencerminkan salah satu pesan kunci yang dirancang untuk dipahami peserta melalui edukasi Literasi media, yakni diperlukan 
adanya konfirmasi terhadap pesan untuk memastikan kebenaran atau keakuratan informasi sebelum seseorang membagikan informasi tersebut.

\section{KESIMPULAN}

Semakin meningkatnya pemanfaatan teknologi informasi dan komunikasi serta internet perlu diikuti dengan peningkatan kemampuan masyarakat untuk memanfaatkan teknologi secara bijak. Ketidakmampuan masyarakat untuk menggunakan teknologi informasi dan komunikasi secara bijak dikarenakan rendahnya literasi masyarakat. Penyelenggaraan Literasi media di Yayasan Perguruan Markus Tangerang merupakan bentuk tanggung jawab sosial Universitas Pelita Harapan melalui Program Studi PJJ Ilmu Komunikasi dalam upaya peningkatan Literasi media. Rangkaian kegiatan Literasi media yang dilakukan melalui seminar, permainan edukatif, dan diskusi kelompok mampu menjadi sarana untuk mengedukasi siswa, guru, dan orang tua terkait pentingnya memiliki kecerdasan dalam pemanfaatan teknologi informasi dan komunikasi.

\section{REFERENSI}

Abedini, Z., Prvizy, S. (2019). The Effect of Group Discussion and Self-Learning on Nursong Students' Civility. DOI: 10.4103/ijnmr.IJNMR_212_18

Asosiasi Pengguna Jasa Internet Indonesia (2018). Potret Zaman Now: Pengguna dan Perilaku Internet Indonesia, Edisi 23 April 2018.

Choi, Gi Woong, Pursel, Barton K, Stubss, Chriss. (2017). Association for Educational Communications \& Technology. TechTrends 61:341-348 DOI 10.1007/s11528-017-0163-7

DailySocialid. (2018). Diakses pada 4 Maret 2019 dari

https://learn.uph.edu/pluginfile.php/662579/mo d resource/content/3/Pedoman\%20TA\%20PJJ \%20Ilkom.pdf

Diskominfo Jateng. "Hoax" tak terkait dengan kebebasan berpendapat. Diakses pada 4 Maret 2019 dari: https://jatengprov.go.id/beritaopd/hoax-takterkait-dengan-kebebasan-berpendapat/

Hootsuite \& We Are Social. (2019). Digital 2019: Essential Insights into how people around the world use internet, mobile device, social media, and e-commerce.

Kemerer, D. (2013). Media Literacy. Communication Research Trend, 32 (1), 4-25.

Nares, Robert. A Glossary; Or, Collection of Words, Phrases, Names and Allusions to Custom, London, 1882,Vol.1: hal. 425.

Herbert, P.C., Rhodes, D., Ramos, J.T., Cichon, T., Baer, H., Cox, C. (2018). Perceived Media Influence on Youth Bullying and Substance Abuse Behaviors. American Journal of Health Studies. Diakses pada 13 September 2019 dari Ebscohost Library

Tully, M., Vraga, E.K. (2017). Effectivenes of a News Media Literacy Advertisement in Partisan versus Nonpartisan Online Media Context: Journal of Broadcasting \& Electronic Media. 61 (1),144-

162.DOI:10.1080/08838151.2016.1273923 